\title{
The Influence of Novel Competence towards Teenagers' Development in South Tangerang
}

\author{
Aryani $^{1}$, Misbah Priagung Nursalim ${ }^{2}$, Zaky Mubarok $^{3}$ \\ \{dosen01161@unpam.ac.id ${ }^{1}$, dosen00942@unpam.ac.id ${ }^{2}$,dosen01639@unpam.ac.id ${ }^{3}$ \}
}

Universitas Pamulang, Banten, Indonesia ${ }^{123}$

\begin{abstract}
This research was motivated by concerns over the low interest in reading among adolescents in Indonesia. When compared with other countries in the world, Indonesian teenagers' interest in reading ranks 60 out of 61 countries. On the other hand, Indonesian teenagers also enjoy consuming hoaxes. This research has two objectives. First, to determine students' reading interest in novels. Second, to determine the influence of novels in shaping students' characters. Researchers visited eight schools in South Tangerang City to map their reading interest and arouse youth reading interest, especially in literary works. This study used a quasi experimental design and non-equivalent control design. In this design, the research subjects were not randomly selected. The researcher divided the subjects into two groups: the experimental group (given reading of teen novels) and the control group (given reading of non-literary works). In these two groups, researchers conducted a personality pretest and posttest. The result, adolescent reading interest was higher than their hobby of reading. Teens also preferred digital reading to printed reading.
\end{abstract}

Keywords: Novels, influence, reading interests.

\section{Pengaruh Kompetensi Novel terhadap Perkembangan Remaja di Tangerang} Selatan

\begin{abstract}
Abstrak. Penelitian ini dilatarbelakangi keperihatinan atas rendahnya minat baca remaja di Indonesia. Jika dibandingkan dengan negara-negara di dunia, minat baca remaja Indonesia menduduki peringkat 60 dari 61 negara. Di sisi lain, remaja Indonesia juga hobi mengonsumi hoax. Penelitian ini memiliki dua tujuan. Pertama, untuk mengetahui minat baca siswa terhadap karya novel. Kedua, untuk mengetahui pengaruh novel dalam membentuk karakter siswa. Peneliti mengunjungi delapan sekolah di Kota Tangerang Selatan untuk memetakan minat baca dan membangkitkan minat baca remaja terutama terhadap karya sastra. Penelitian ini menggunakan quasi experimental design dan nonequivalent control design. Pada desain ini, subjek penelitian tidak dipilih secara acak. Peneliti membagi subjek menjadi dua kelompok: kelompok eksperimen (diberi bacaan novel remaja) dan kelompok kontrol (diberi bacaan non-karya sastra). Pada kedua kelompok ini, peneliti melakukan pretest dan posttest kepribadian. Hasilnya, minat baca remaja lebih tinggi daripada hobi membaca. Remaja juga lebih menyukai bacaan digital daripada bacaan cetak.
\end{abstract}

Kata kunci: Novel, pengaruh, minat baca. 


\section{Pendahuluan}

Pertumbuhan teknologi informasi di dunia membuat orang dengan mudah menerima dan menyebarluaskan informasi. Indonesia menjadi salah satu pasar industri teknologi informasi global. Jika dulu gawai hanya bisa digunakan untuk berkirim suara dan pesan tulisan, kini gawai dilengkapi internet yang mampu menerima dan mengirim apa saja. Salah satu yang paling mudah didapat melalui internet yaitu informasi hoax. Hoax menyebar di semua jejaring sosial seperti whatsapp, facebook, instagram, twitter, dan sebagainya. Mudahnya membaca melalui gawai membuat orang mulai tertarik membaca. Salah satu yang dapat dibaca di jejaring sosial tersebut adalah informasi hoax tersebut. Minimnya pengetahuan dan malasnya mencari tahu kebenaran setiap informasi yang didapat, membuat banyak orang terprovokasi hoax. Penyebaran hoax ini dapat dikendalikan dengan mengubah kebiasaan dan pola pikir masyarakat, dari membaca informasi yang ada di media sosial ke membaca literatur sastra. Pengendalian terhadap informasi hoax ini menjadi tanggung jawab bersama. Salah satu upaya yang dapat dilakukan adalah mengubah pola pikir masyarakat untuk beralih menjadi pembaca literatur sastra.

Presiden Republik Indonesia, Joko Widodo menyerukan revolusi mental masyarakat Indonesia ${ }^{1}$. Dari mental korupsi menjadi jujur, dari malas menjadi giat. Hal tersebut bukanlah hal yang mudah, namun bukan berarti tidak bisa dilakukan. Penelitian ini menjadi sangat penting untuk mewujudkan revolusi mental masyarakat Indonesia, terutama kaum remaja. Penulis menganggap bahwa karya sastra merupakan cara tepat untuk mengubah mental remaja menjadi lebih baik. Horatio memberikan ciri khas pada karya sastra [1]. Ia mengatakan bahwa karya sastra bersifat indah dan bermanfaat. Karya sastra dibuat pengarang melalui imajinasinya yang dikemas dalam rangkaian kata yang di dalamnya menyimpan keindahan makna. Selain itu juga bermanfaat bagi pembacanya; untuk menghibur hati, pelipur lara, bahkan ada juga karya sastra yang digunakan untuk menolak bala.

Membaca merupakan proses merekonstruksi kembali gagasan atau ide yang terdapat dalam sebuah teks/tulisan serta informasi yang digagas oleh penulis. Pengertian membaca, menurut Abidin, adalah aktivitas yang dilakukan agar dapat memperoleh informasi di dalam bahan bacaan. Produk membaca merupakan hasil dari proses membaca yakni pemahaman atas isi bacaan [2]. Nursalim dan Aryani menjelaskan bahwa membaca merupakan kegiatan memahami informasi yang disampaikan melalui tulisan [3]. Dengan membaca otak akan berkembang dan membantu membantuk pribadi yang lebih berpikir sederhana dalam menyikapi permasalahan. Membaca terbukti ampuh meningkatkan kualitas SDM.

Karya sastra mampu mengubah karakter seseorang karena di dalamnya menyimpan ideologi yang disampaikan pengarang. Kitab Mahabharata yang diciptakan Begawan Vyasa, di dalamnya mengajarkan bagaimana cara berpolitik, keagamaan, petuah hidup, dan sebagainya. Kitab tersebut kemudian digubah oleh Raden Sahid dalam bentuk wayang kulit sebagai media penyebaran ajaran Islam di tanah Jawa.

Novak menjelaskan bahwa karakter merupakan campuran kompatibel dari seluruh kebaikan yang diidentifikasi oleh tradisi religius, cerita sastra, kaum bijaksana, dan kumpulan orang berakal sehat yang ada dalam sejarah [4]. Karakter berasal dari bahasa latin charassein, yang berarti "membuat tajam" atau "membuat dalam" [5].

Banyak orang yang berubah pemikirannya setelah menikmati karya sastra.Tahun 2004, banyak remaja puteri termotivasi berhijab setelah membaca novel Ayat-Ayat Cinta karya Habiburrahman el-Syirazi [10]. Tahun 2009 banyak remaja yang kemudian menjalani hobi baru; mendaki gunung setelah membaca novel 5 CM karya Doni Dirgantoro [11]. Karya sastra mampu memberikan suntikan moral dan memengaruhi pembacanya. Cara ini lebih efektif 
daripada memberikan ceramah atau memaksa dengan kekerasan. Hal itu karena membaca karya sastra melampaui alam bawah sadar pembaca, sehingga pesan yang disampaikan merasuk ke dalam jiwanya. Hal itu membuat jiwa remaja tergerak untuk berubah seperti tokoh dalam novel tersebut. Ketika menulis, pengarang memiliki publik yang hadir dalam pikirannya, paling tidak dirinya sendiri [6].

Namun, agaknya cara ini sedikit lebih sulit dari yang diduga karena minat baca remaja terhadap karya sastra sangat rendah. Maka dari itu, penulis melakukan penelitian tentang pengaruh karya sastra terhadap perkembangan remaja di Tangerang Selatan. Selain meneliti, penulis juga memberikan pelatihan kepada responden tentang bagaimana cara membaca karya sastra yang menyenangkan. Serta memberikan pendampingan kepada mereka selama proses penelitian. Proses pengambilan data akan dilaksanakan di beberapa daerah yang dipilih secara acak. Selain untuk mengamati kompetensi remaja juga untuk memetakan tingkat membaca di suatu daerah yang akan kami jadikan sebagai objek penelitian.

Berdasarkan latar belakang yang sudah dipaparkan di atas, masalah dalam penelitian ini dirumuskan untuk mengetahui pemahaman remaja sekolah menengah di Tangerang Selatan terhadap karya sastra novel dan mengetahui pengaruh novel terhadap remaja sekolah menengah di Tangerang Selatan. Pemahaman remaja terhadap karya sastra novel dilakukan untuk meningkatkan minat baca terhadap karya sastra. Pengukuran pengaruh karya sastra novel terhadap perkembangan remaja dilakukan untuk mengetahui dampak yang ditimbulkan setelah remaja membaca karya sastra berupa novel.

\section{Metode}

Langkah konkrit yang diambil untuk pelaksanaan penelitian adalah dengan menentukan metodenya [4]. Penelitian ini adalah penelitian ekperimen. Penelitian eksprimen digunakan untuk melihat perubahan akibat perlakuan pada suatu kelompok yang terkontrol. Eksperimen digunakan untuk membaca hubungan sebab-akibat antara variabel terikat dan variabel bebas. Penelitian ini menggunakan pendekatan asosiatif yang bertujuan untuk mngetahui pengaruh hubungan dua variable atau lebih [5].

Penulis menggunakan quasi experimental design dan non-equivalent control group design. Pada disain ini, subjek penelitian tidak dipilih secara random. Penulis akan membagi subjek menjadi satu kelompok eksperimen (diberikan bacaan novel remaja) dan satu kelompok kontrol diberikan bacaan (non-karya sastra). Pada kedua kelompok ini, Penulis melakukan pretest dan posttest kepribadian. Berikut adalah skema penelitian yang akan dilakukan. Waktu yang digunakan dalam ekperimen ini adalah satu semester ( 2 bulan) dengan pengecekan dan pengontrolan 4 kali dalam satu bulan

Sumber data penelitian merupakan subjek dari mana data penelitian dapat diperoleh. Data merupakan segala sumber informasi bisa juga bahan yang diamati. Data dalam penelitian ini adalah hasil survei yang dilakukan sebanyak dua tahap. Sumber data primer yang digunakan dalam penelitian ini yaitu para pelajar se-Kota Tangerang Selatan. Pengumpulan data merupakan upaya Penulis untuk mendapatkan data secukupnya. Teknik pengumpulan data menggunakan survei melalui Google Formulir.

Pelaksanaan pengumpulan data dilakukan pada kurun Juli hingga September 2020 pada siswa 8 sekolah di wilayah Tangerang Selatan meliputi SMP Djodjoredjo, SMP Negeri 21 Tangerang Selatan, SMP Negeri 8 Kota Tangerang Selatan, SMK 2 Nusantara, SMA Nusantara, SMK Kesehatan Riksa Indrya, SMK Kesehatan Puspita Husada, dan SMK Putra 
Satria. Penelitian dilakukan sebanyak 2 tahap. Tahap pertama bersifat survei awal (pretest) digunakan untuk mengetahui minat baca remaja terhadap bahan bacaan dan mengetahui jenis bacaan yang disukai siswa.

Tahap kedua dilakukan untuk mengukur tingkat baca remaja terhadap bahan bacaan sastra serta pengaruhnya terhadap pembaca. Survei tahap kedua ini dilakukan sebanyak 2 kali. Pertama, remaja diberikan bahan bacaan novel digital berupa novel petualangan kemudian diukur tingkat baca dan pengaruhnya bagi pembaca. Kedua, remaja diberikan 3 bahan bacaan secara acak untuk dibaca. Kemudian, dilakukan survei untuk mengukur tingkat baca dan pengaruhnya bagi pembaca.

Analisis data merupakan kegiatan setelah data dari seluruh responden atau sumber lain terkumpul [6]. Dalam penelitian ini dilakukan 2 pengujian analisis data yaitu uji prasyarat analisis dan uji hipotesis. Uji prasyarat analisis yaitu dengan pengujian normalitas dan homogenitas antara subyek kelompok eksperimen dengan subjek kelompok kontrol dan selanjutnya dilakukan uji hipotesis antara kelompok eksperimen dan kelompok kontrol.

a. Uji normalitas sebaran digunakan untuk memeriksa apakah data yang diperoleh dari masing-masing variabel distribusi normal atau tidak. Perhitungan uji normalitas pada penelitian ini menggunakan uji normalitas data kolmogorov-smirnov yang dihitung dengan bantuan SPSS for windows release 16.

b. Uji homogenitas varian. Sebagaimana yang dikemukakan oleh Santosa [7] bahwa uji homogenitas yaitu untuk mengetahui apakah kedua kelompok mempunyai rata-rata yang sama atau tidak. Uji homogenitas yang digunakan dalam penelitian ini yaitu uji anova dengan bantuan SPSS for windows release 16. Asumsi yang digunakan dalam pengujian ini yaitu jika data bertipe kuantitatif, baik itu interval atau rasio, data berdistribusi normal, dan data berjumlah sedikit.

c. Uji hipotesis pada penelitian perlu diuji untuk membuktikan kebenaran dari hipotesis yang telah dirumuskan sebelumnya. Dalam pengujian hipotesis ini peneliti menggunakan uji independent sample $t$ test dengan bantuan SPSS for windows release 16. Singgih Santosa (2014: 79) [7] menyatakan bahwa uji independent sample $t$ test adalah uji hipotesis ini digunakan untuk membandingkan rata-rata dari dua grup yang tidak berhubungan satu dengan yang lain, dengan tujuan apakah kedua grup tersebut mempunyai rata-rata yang sama atau tidak.

\section{Hasil dan Pembahasan}

\subsection{Profil Remaja Usia Sekolah di Tangerang Selatan}

Tangerang selatan (Tangsel) merupakan salah satu kota yang berada di Provinsi Banten. Tangsel merupakan pemekaran dari Kabupaten Tangerang melalui Menteri Dalam Negeri pada 29 Oktober 2008. Tangsel memiliki motto Cerdas, Modern, dan Religius. Berupaya untuk mencerdaskan masyarakat, Tangsel memiliki berbagai sarana dan fasilitas pendidikan dari tingkat dasar hingga perguruan tinggi. Tangsel memiliki 198 sekolah menengah pertama dan 90 sekolah menengah atas. Jumlah remaja sekolah menengah pertama di tangsel sebanyak 55.247 siswa. Adapun jumlah remaja siswa menengah akhir sebanyak 60.166 siswa, yang terdiri dari 27.598 siswa SMA dan 32.568 siswa SMK ${ }^{2}$. 


\subsection{Hasil Analisis}

Penelitian ini dilakukan di delapan sekolah dalam wilayah Tangerang Selatan, meliputi SMP Djodjoredjo, SMP Negeri 21 Tangerang Selatan, SMP Negeri 8 Kota Tangerang Selatan, SMK 2 Nusantara, SMA Nusantara, SMK Kesehatan Riksa Indrya, SMK Kesehatan Puspita Husada, dan SMK Putra Satria. Penelitian dilakukan sebanyak 2 tahap. Tahap pertama bersifat survei awal (pretest) digunakan untuk mengetahui minat baca remaja terhadap bahan bacaan dan mengetahui jenis bacaan yang disukai siswa.

Tahap kedua dilakukan untuk mengukur tingkat baca remaja terhadap bahan bacaan sastra serta pengaruhnya terhadap pembaca. Survei tahap kedua ini dilakukan sebanyak 2 kali. Pertama, remaja diberikan bahan bacaan novel digital berupa novel petualangan kemudian diukur tingkat baca dan pengaruhnya bagi pembaca. Kedua, remaja diberikan 3 bahan bacaan secara acak untuk dibaca. Kemudian, dilakukan survei untuk mengukur tingkat baca dan pengaruhnya bagi pembaca.

\section{Survei Minat Membaca}

Survei minat baca disebarkan kepada remaja sekolah di 8 sekolah di wilayah Tangserang Selatan. Sebanyak 500 siswa mengisi kuesinoer. Hasil survei awal (Pretest) minat baca remaja terhadap bahan bacaan didapatkan hasil:

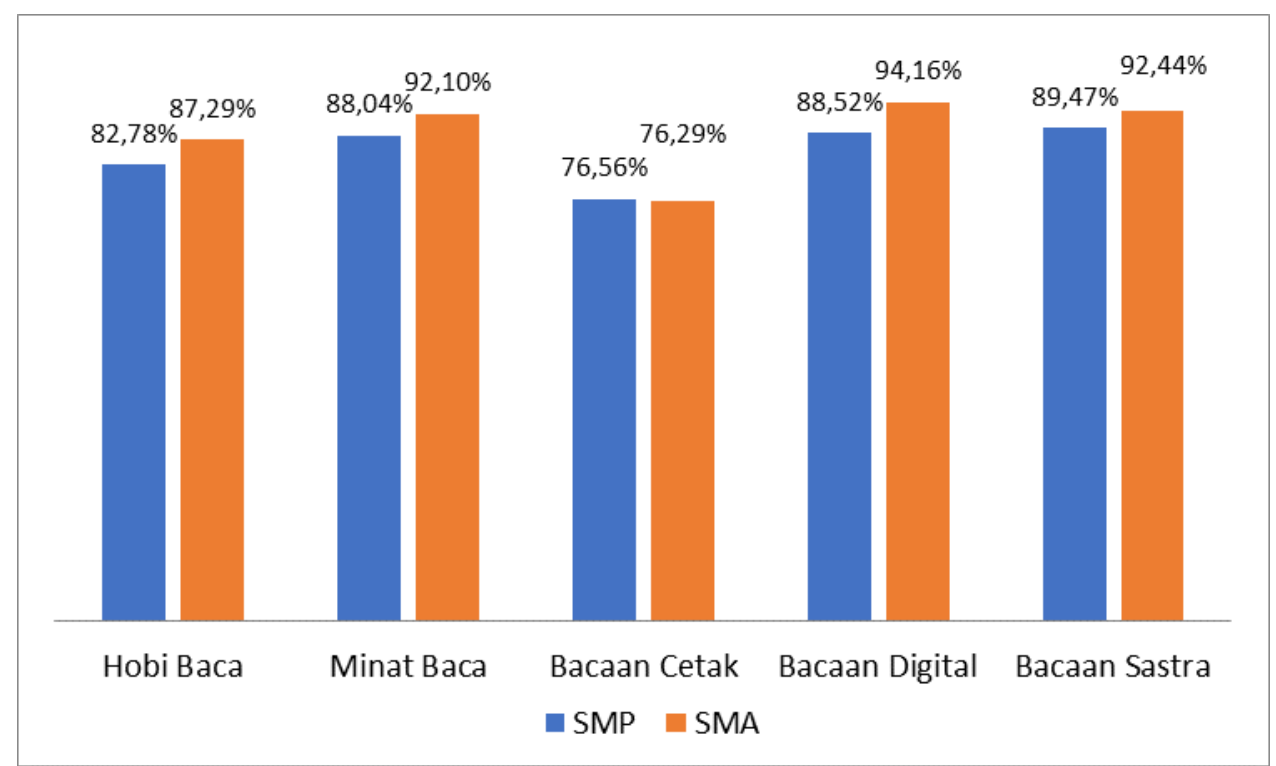

Gambar 1. Diagram persentase minat baca siswa remaja berdasarkan tingkat sekolah di Tangerang Selatan berdasarkan tingkat sekolah.

Dari data tersebut didapatkan bahwa $82,78 \%$ total responden siswa SMP memiliki hobi membaca dan $87,29 \%$ siswa SMA memililiki hobi membaca. Secara keseluruhan $85,40 \%$ siswa memiliki hobi membaca. 


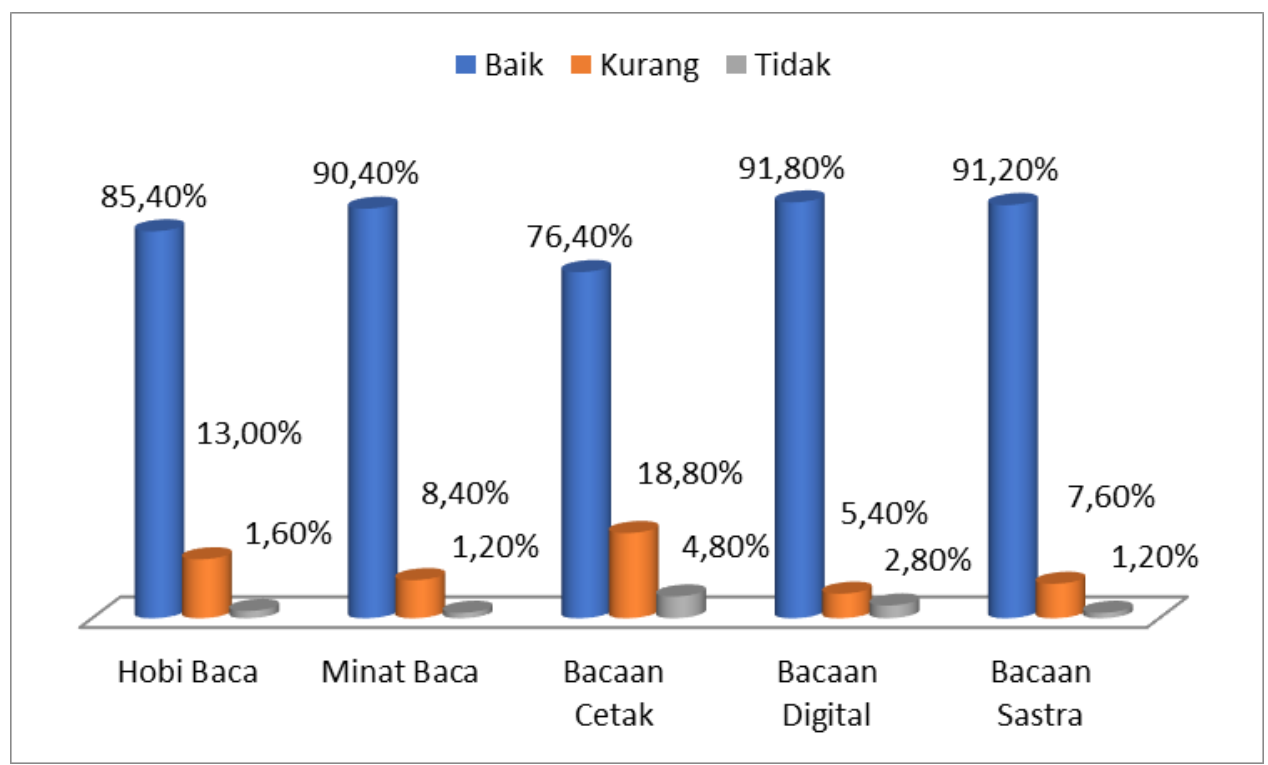

Gambar 2. Diagram persentase minat baca siswa remaja berdasarkan tingkat sekolah di Tangerang Selatan secara umum.

Remaja usia sekolah menengah memiliki minat membaca yang tinggi, yakni total $90,40 \%$, dengan rincian $88,04 \%$ remaja sekolah menengah pertama dan 92,10\% remaja siswa menengah atas. Tingginya minat daripada hobi terjadi karena hobi lebih pada progres. Adapun minat masih berupa program. Beberapa remaja tidak merealisasikan minat baca menjadi hobi karena minimnya akses bahan bacaannya. Untuk mendukung minat baca siswa, kami melakukan pengukuran terhadap media baca siswa. Sebanyak 76,40\% remaja sekolah menengah suka membaca media cetak, dengan rincian 76,56\% pada siswa SMP dan 76,29\% pada siswa SMA. Ketertarikan pada media bacaan cetak lebih sedikit dibandingkan dengan ketertarikan pada media bacaan digital. Sebanyak 91,80\% siswa sekolah menengah di Tangerang Selatan suka membaca media bacaan digital dengan rincian $88,52 \%$ pada siswa SMP dan 94,16\% pada siswa SMA.

Remaja usia sekolah menengah di Tangerang Selatan minat baca terhadap karya sastra sangat tinggi yakni $91,20 \%$ dengan rincian $89.47 \%$ pada tingkat SMP dan $92,44 \%$ pada tingkat SMA. Melihat kondisi tersebut kemudian dilakukan pengukuran lebih mendalam untuk mengetahui tema bacaan sastra yang paling disukai remaja. 


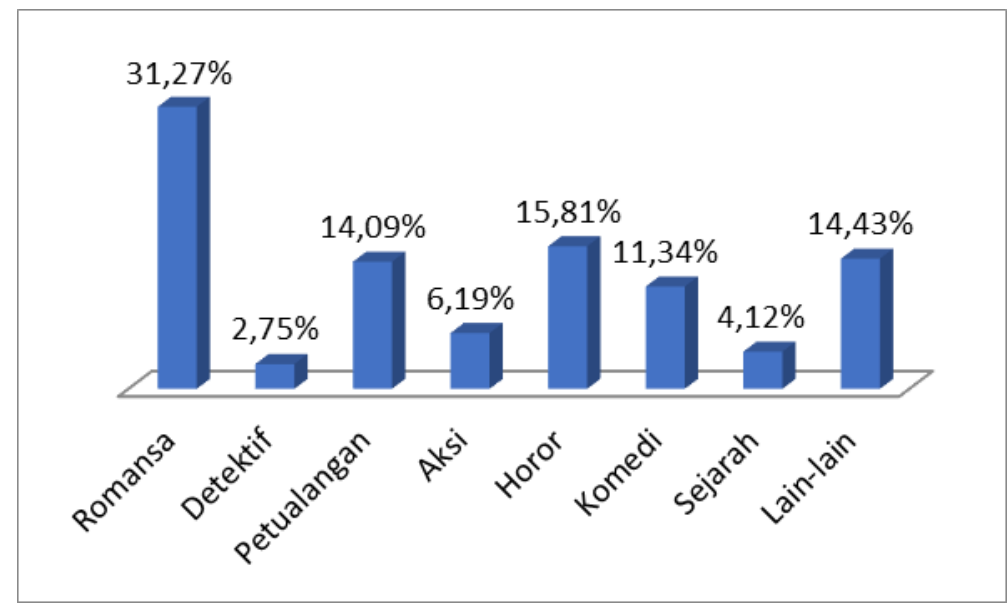

Gambar 3. Diagram persentase minat tema bacaan siswa remaja di Tangerang Selatan

Pengukuran terhadap tema bacaan sastra bagi remaja sekolah menengah di Tangsel lebih pada bacaan prosa. Pengukuran minat baca terhadap genre prosa didapatkan hasil 31,27\% siswa lebih suka membaca karya sastra romansa. Sastra genre horor sebanyak $15,81 \%$. Minat baca terhadap genre petualangan sebanyak 14,09\%. Genre komedi berada di urutak keempat sebagai genre cerita yang disukai siswa yakni sebanyak 11,34\%. Genre aksi berada pada peringkat kelima yang disukai yakni sebanyak 6,19\%. Novel sejarah berada di posisi keenam dengan peminat sebanyak $4,12 \%$. Adapun novel detektif berada di urutan ketujuh dengan $2,75 \%$ peminat. Sebanyak $14,43 \%$ siswa cenderung menyukai genre novel yang lain.

\section{Minat Baca remaja SMP di Tangerang Selatan}

Adapun penjelasan hasil survei awal minat baca remaja SMP dalam bentuk tabel sebagai berikut:

Tabel 1. Remaja SMP yang Hobi Membaca

\begin{tabular}{rlrrrr}
\hline & & Frequency & Percent & Valid Percent & Cumulative Percent \\
\hline \multirow{4}{*}{ Valid } & Sangat Baik & 17 & 8.1 & 8.1 & 8.1 \\
& Baik & 86 & 41.1 & 41.1 & 49.3 \\
& Cukup & 70 & 33.5 & 33.5 & 82.8 \\
& Kurang & 34 & 16.3 & 16.3 & 99.0 \\
& Tidak & 2 & 1.0 & 1.0 & 100.0 \\
& Total & 209 & 100.0 & 100.0 & \\
\hline
\end{tabular}

Remaja SMP yang memiliki hobi membaca sangat baik sebanyak 17 siswa $(8,1 \%)$. Adapun 86 siswa $(41,1 \%)$ memiliki hobi membaca yang baik. Remaja yang memiliki hobi membaca cukup baik sebanyak 70 siswa $(33,5 \%)$. Adapun 34 siswa SMP (16,3\%) kurang hobi membaca. Selanjutnya, sebanyak 2 siswa (1\%) tidak memiliki hobi membaca sama sekali. 
Tabel 2. Remaja SMP yang Memiliki Minat untuk Membaca

\begin{tabular}{rlrrrr}
\hline & & Frequency & Percent & Valid Percent & Cumulative Percent \\
\hline \multirow{4}{*}{ Valid } & 24 & 11.5 & 11.5 & 11.5 \\
& Sangat Baik & 104 & 49.8 & 49.8 & 61.2 \\
& Baik & 56 & 26.8 & 26.8 & 88.0 \\
& Cukup & 23 & 11.0 & 11.0 & 99.0 \\
& Kurang & 2 & 1.0 & 1.0 & 100.0 \\
& Tidak & 209 & 100.0 & 100.0 & \\
& Total & & & &
\end{tabular}

Remaja SMP yang memiliki minat untuk membaca sangat baik sebanyak 24 siswa $(11,5 \%)$. Adapun 104 siswa $(49,8 \%)$ memiliki minat membaca yang baik. Remaja yang memiliki minat membaca cukup baik sebanyak 56 siswa (26,8\%). Adapun 23 siswa SMP $(11,0 \%)$ kurang minat membaca. Sebanyak 2 siswa (1\%) tidak memiliki minat baca sama sekali.

Tabel 3. Kepeminatan Remaja SMP terhadap Bahan Bacaan Cetak

\begin{tabular}{rlrrrr}
\hline & & Frequency & Percent & Valid Percent & Cumulative Percent \\
\hline \multirow{4}{*}{ Valid } & Sangat Baik & 14 & 6.7 & 6.7 & 6.7 \\
& Baik & 81 & 38.8 & 38.8 & 45.5 \\
& Cukup & 65 & 31.1 & 31.1 & 76.6 \\
& Kurang & 41 & 19.6 & 19.6 & 96.2 \\
& Tidak & 8 & 3.8 & 3.8 & 100.0 \\
& Total & 209 & 100.0 & 100.0 & \\
\hline
\end{tabular}

Remaja SMP yang memiliki minat untuk membaca bahan bacaan cetak sangat baik sebanyak 14 siswa (6,7\%). Adapun 81 siswa (38,8\%) memiliki minat membaca yang baik terhadap bahan bacaan cetak. Remaja yang memiliki minat membaca cukup baik terhadap bahan bacaan cetak sebanyak 65 siswa $(31,1 \%)$. Adapun 41 siswa SMP $(19,6 \%)$ kurang minat membaca bahan bacaan cetak. Selanjutnya, sebanyak 8 siswa $(3,8 \%)$ tidak memiliki minat membaca bahan bacaan cetak sama sekali.

Tabel 4. Kepeminatan Remaja SMP terhadap Bahan Bacaan Digital

\begin{tabular}{|c|c|c|c|c|c|}
\hline & & Frequency & Percent & Valid Percent & Cumulative Percent \\
\hline \multirow{6}{*}{ Valid } & Sangat Baik & 72 & 34.4 & 34.4 & 34.4 \\
\hline & Baik & 72 & 34.4 & 34.4 & 68.9 \\
\hline & Cukup & 41 & 19.6 & 19.6 & 88.5 \\
\hline & Kurang & 17 & 8.1 & 8.1 & 96.7 \\
\hline & Tidak & 7 & 3.3 & 3.3 & 100.0 \\
\hline & Total & 209 & 100.0 & 100.0 & \\
\hline
\end{tabular}

Remaja SMP yang memiliki kesukaan membaca bahan bacaan digital yang sangat baik sebanyak 72 siswa $(34,4 \%)$. Begitu juga 72 siswa $(34,4 \%)$ memiliki minat membaca bahan bacaan digital yang baik. Remaja yang memiliki minat membaca bacaan digital cukup baik sebanyak 41 siswa $(19,6 \%)$. Adapun 17 siswa SMP $(8,1 \%)$ kurang minat membaca bacaan digital. Sementara sebanyak 7 siswa $(3,3 \%)$ tidak memiliki minat baca bahan bacaan digital sama sekali. 
Tabel 4. Kesukaan Remaja SMP terhadap Karya Sastra

\begin{tabular}{rlrrrr}
\hline & & Frequency & Percent & Valid Percent & Cumulative Percent \\
\hline \multirow{4}{*}{ Valid } & Sangat Baik & 82 & 39.2 & 39.2 & 39.2 \\
& Baik & 74 & 35.4 & 35.4 & 74.6 \\
& Cukup & 31 & 14.8 & 14.8 & 89.5 \\
& Kurang & 20 & 9.6 & 9.6 & 99.0 \\
& Tidak & 2 & 1.0 & 1.0 & 100.0 \\
& Total & 209 & 100.0 & 100.0 & \\
\hline
\end{tabular}

Remaja SMP yang memiliki kesukaan membaca karya sastra yang sangat baik sebanyak 82 siswa (39,2\%). Adapun 74 siswa $(35,4 \%)$ memiliki minat membaca yang baik terhadap karya sastra. Remaja yang memiliki minat membaca karya sastra yang cukup baik sebanyak 31 siswa (14,8\%). Adapun 20 siswa SMP (9,6\%) kurang minat membaca karya sastra. Sementara sebanyak 2 siswa (1\%) tidak suka membaca karya sastra.

Tabel 5. Genre Cerita yang Disukai Remaja SMP

\begin{tabular}{|c|c|c|c|c|c|}
\hline & & Frequency & Percent & Valid Percent & Cumulative Percent \\
\hline \multirow{9}{*}{ Valid } & Romansa & 17 & 8.1 & 8.1 & 8.1 \\
\hline & Detektif & 7 & 3.3 & 3.3 & 11.5 \\
\hline & Petualangan & 51 & 24.4 & 24.4 & 35.9 \\
\hline & Aksi & 21 & 10.0 & 10.0 & 45.9 \\
\hline & Horor & 42 & 20.1 & 20.1 & 66.0 \\
\hline & Komedi & 31 & 14.8 & 14.8 & 80.9 \\
\hline & Sejarah & 18 & 8.6 & 8.6 & 89.5 \\
\hline & Lain-lain & 22 & 10.5 & 10.5 & 100.0 \\
\hline & Total & 209 & 100.0 & 100.0 & \\
\hline
\end{tabular}

Pengukuran terhadap tema bacaan sastra bagi remaja SMP di Tangsel lebih pada bacaan prosa. Pengukuran minat baca terhadap genre prosa didapatkan hasil $17(8,1 \%)$ siswa lebih suka membaca karya sastra romansa. Sastra genre horor sebanyak $42(20,1 \%)$ siswa. Minat baca terhadap genre petualangan sebanyak 51 (24,2\%) siswa. Genre komedi berada di urutan ketiga sebagai genre cerita yang disukai siswa yakni sebanyak $31(14,8 \%)$. Genre aksi berada pada peringkat kelima yang disukai yakni sebanyak $21(10 \%)$ siswa. Novel sejarah berada di posisi keenam dengan peminat sebanyak $18(8,6 \%)$ siswa. Adapun novel detektif berada diurutan kedelapan dengan 7 (3,3\%) siswa peminat. Sebanyak $22(10,5) \%$ siswa cenderung menyukai genre novel yang lain.

Minat Baca remaja SMA/SMK di Tangerang Selatan

Adapun penjelasan hasil survei awal minat baca remaja SMA/SMK dalam bentuk tabel sebagai berikut:

\begin{tabular}{rlrrrr}
\multicolumn{2}{c}{ Tabel 6. Siswa SMA/SMK di Tangerang Selatan yang Hobi Membaca } \\
\hline \multicolumn{1}{c}{ Frequency } & Percent & Valid Percent & $\begin{array}{c}\text { Cumulative } \\
\text { Percent }\end{array}$ \\
\hline \multirow{4}{*}{ Valid } & & & & 7.9 & 7.9 \\
& Sangat Baik & 23 & 7.9 & 48.5 & 56.4 \\
& Baik & 141 & 48.5 & 30.9 & 87.3 \\
& Cukup & 90 & 30.9 & 10.7 & 97.9 \\
& Kurang & 31 & 10.7 & 2.1 & 100.0 \\
& Tidak & 6 & 2.1 & 100.0 & \\
Total & 291 & 100.0 & &
\end{tabular}


Dapat disimpulkan bahwa sebanyak $2,1 \%$ siswa SA/SMK di Tangerang Selatan yang tidak memiliki hobi membaca. Sementara sebanyak $10,7 \%$ siswa kurang hobi membaca. Sisanya sebanyak $87,2 \%$ siswa memiliki hobi membaca dengan rincian $7,9 \%$ siswa sangat hobi membaca. Sebanyak 48,5\% siswa hobi membaca. Sebanyak 30,9\% siswa memiliki hobi membaca yang cukup.

Tabel 7. Minat untuk Membaca Siswa SMA/SMK di Tangerang Selatan

\begin{tabular}{rlrrrr}
\hline & & Frequency & Percent & Valid Percent & Cumulative Percent \\
\hline \multirow{4}{*}{ Valid } & Sangat Baik & 33 & 11.3 & 11.3 & 11.3 \\
& Baik & 161 & 55.3 & 55.3 & 66.7 \\
& Cukup & 74 & 25.4 & 25.4 & 92.1 \\
& Kurang & 19 & 6.5 & 6.5 & 98.6 \\
& Tidak & 4 & 1.4 & 1.4 & 100.0 \\
& Total & 291 & 100.0 & 100.0 & \\
\hline
\end{tabular}

Sebanyak 1,4\% siswa SMA/SMK di Tangerang Selatan tidak memiliki hobi membaca. Sebanyak 6,5\% siswa SMA/SMK di Tangerang Selatan kurang berminat membaca. Sisanya sebanyak $92,1 \%$ siswa memiliki minat membaca. Adapun rinciannya sebanyak $11,3 \%$ siswa memiliki minat baca yang sangat baik, sebanyak 55,35 siswa memiliki minat baca yang baik, dan sebanyak $25,4 \%$ siswa memiliki minat baca yang cukup.

Tabel 7. Ketertarikan Siswa SMA/SMK di Tangerang Selatan terhadap Bahan Bacaan Cetak

\begin{tabular}{rlrrrr}
\hline & & Frequency & Percent & Valid Percent & Cumulative Percent \\
& Sangat Baik & 19 & 6.5 & 6.5 & 6.5 \\
& Baik & 109 & 37.5 & 37.5 & 44.0 \\
\multirow{4}{*}{ Valid } & Cukup & 94 & 32.3 & 32.3 & 76.3 \\
& Kurang & 53 & 18.2 & 18.2 & 94.5 \\
& Tidak & 16 & 5.5 & 5.5 & 100.0 \\
& Total & 291 & 100.0 & 100.0 & \\
\hline
\end{tabular}

Sebanyak 5,5 \% siswa SMA/SMK di Tangerang Selatan tidak tertarik membaca bahan bacaan cetak. Sebanyak 18,2\% siswa SMA/SMK di Tangerang Selatan kurang tertarik membaca bahan bacaan cetak. Sisanya sebanyak $76,3 \%$ siswa memiliki minat membaca bahan bacaan cetak. Adapun rinciannya sebanyak 6,5\% siswa memiliki minat baca yang sangat baik terhadap bahan bacaan cetak, sebanyak $37,5 \%$ siswa memiliki minat baca yang baik terhadap bahan bacaan cetak, dan sebanyak 32,3\% siswa memiliki minat baca yang cukup terhadap bahan bacaan cetak.

Tabel 8. Ketertarikan Siswa SMA/SMK di Tangerang Selatan terhadap Bahan Bacaan Digital

\begin{tabular}{rlrrrr}
\hline & & Frequency & Percent & Valid Percent & Cumulative Percent \\
\hline \multirow{6}{*}{ Valid } & 141 & 48.5 & 48.5 & 48.5 \\
& Sangat Baik & 100 & 34.4 & 34.4 & 82.8 \\
& Baik & 33 & 11.3 & 11.3 & 94.2 \\
& Cukup & 10 & 3.4 & 3.4 & 97.6 \\
& Kurang & 7 & 2.4 & 2.4 & 100.0 \\
& Tidak & 291 & 100.0 & 100.0 & \\
& Total & & &
\end{tabular}


Sebanyak 2,4 \% siswa SMA/SMK di Tangerang Selatan tidak tertarik membaca bahan bacaan digital. Sebanyak 3,4\% siswa SMA/SMK di Tangerang Selatan kurang tertarik membaca bahan bacaan digital. Sisanya sebanyak $94,2 \%$ siswa memiliki minat membaca bahan bacaan digital. Adapun rinciannya sebanyak 48,5\% siswa memiliki minat baca yang sangat baik terhadap bahan bacaan digital, sebanyak $34,4 \%$ siswa memiliki minat baca yang baik terhadap bahan bacaan cetak, dan sebanyak 11,3\% siswa memiliki minat baca yang cukup terhadap bahan bacaan cetak.

Tabel 9. Ketertarikan Siswa SMA/SMK di Tangerang Selatan terhadap Karya Sastra

\begin{tabular}{rlrrrr}
\hline & & Frequency & Percent & Valid Percent & Cumulative Percent \\
\hline \multirow{6}{*}{ Valid } & Sangat Baik & 108 & 37.1 & 37.1 & 37.1 \\
& Baik & 117 & 40.2 & 40.2 & 77.3 \\
& Cukup & 44 & 15.1 & 15.1 & 92.4 \\
& Kurang & 18 & 6.2 & 6.2 & 98.6 \\
& Tidak & 4 & 1.4 & 1.4 & 100.0 \\
& Total & 291 & 100.0 & 100.0 & \\
\hline
\end{tabular}

Sebanyak 1,4 \% siswa SMA/SMK di Tangerang Selatan tidak tertarik membaca karya sastra. Sebanyak 6,2\% siswa SMA/SMK di Tangerang Selatan kurang tertarik membaca karya sastra. Sisanya sebanyak $92,4 \%$ siswa memiliki minat membaca karya sastra. Adapun rinciannya sebanyak $37,1 \%$ siswa memiliki minat baca yang sangat baik terhadap karya sastra, sebanyak 40,2\% siswa memiliki minat baca yang baik terhadap karya sastra, dan sebanyak $15,1 \%$ siswa memiliki minat baca yang cukup terhadap karya sastra.

Tabel 10. Genre Cerita yang Disukai Siswa SMA/SMK di Tangerang Selatan

\begin{tabular}{llrrrr}
\hline & Frequency & Percent & Valid Percent & Cumulative Percent \\
\hline & Romansa & 91 & 31.3 & 31.3 & 31.3 \\
& Detektif & 8 & 2.7 & 2.7 & 34.0 \\
& Petualangan & 41 & 14.1 & 14.1 & 48.1 \\
& Aksi & 18 & 6.2 & 6.2 & 54.3 \\
Valid & 46 & 15.8 & 15.8 & 70.1 \\
& Horor & 33 & 11.3 & 11.3 & 81.4 \\
& Komedi & 12 & 4.1 & 4.1 & 85.6 \\
& Sejarah & 14.4 & 14.4 & 100.0 \\
& Lain-lain & 42 & 100.0 & \\
Total & 291 & 100.0 & & \\
\hline
\end{tabular}

Siswa SMA/SMK di Tangerang selatan lebih menyukai cerita bertema romansa dibanding yang lain. Hal itu dibuktikan dengan $31,3 \%$ siswa menyukai cerita romansa. Cerita horror berada di urutan kedua dengan $15,8 \%$ siswa. Sementara, cerita lainnya berada di urutan ketiga dengan jumlah $14,4 \%$.

\section{Pemahaman dan Pengaruh Novel Teror di Gunung Ciremai}

Pemahaman Kompetensi Novel Teror di Gunung Ciremai terhadap Perkembangan Remaja $S M P$

Novel teror di Gunung Ciremai merupakan novel anonim yang dipublikasikan oleh akun Xaverius Endro melalui akun facebook-nya. Novel tersebut menceritakan dua orang pendaki gunung yang mengalami teror dari makhluk penunggu Gunung Ciremai setelah salah satu di antara mereka membuang pembalut bekas sembarangan. 
Adapun penjelasan pengaruh kompetensi novel terhadap perkembangan remaja sekolah menengah pertama di Tangerang Selatan sebagai berikut :

Tabel 11. Pemahaman Siswa SMP terhadap Pesan Moral pada Novel Teror di Gunung Ciremai

\begin{tabular}{rlrrrr}
\hline & & Frequency & Percent & Valid Percent & Cumulative Percent \\
\hline \multirow{4}{*}{ Valid } & Sangat Baik & 20 & 48.8 & 48.8 & 48.8 \\
& Baik & 14 & 34.1 & 34.1 & 82.9 \\
& Cukup & 5 & 12.2 & 12.2 & 95.1 \\
& Tidak & 2 & 4.9 & 4.9 & 100.0 \\
& Total & 41 & 100.0 & 100.0 & \\
\hline
\end{tabular}

Novel Teror di Gunung Ciremai menurut sebagian besar pembaca usia SMP memiliki pesan moral. Sebanyak $95,1 \%$ pembaca menganggap novel tersebut memiliki pesan moral. Hanya $4,9 \%$ pembaca yang menyatakan bahwa novel tersebut tidak memberikan pesan moral terhadap pembaca.

Tabel 12. Genre Cerita yang Disukai Siswa SMA/SMK di Tangerang Selatan

\begin{tabular}{rlrrrr}
\hline & & Frequency & Percent & Valid Percent & Cumulative Percent \\
\hline \multirow{4}{*}{ Valid } & 11 & 26.8 & 26.8 & 26.8 \\
& Sangat Baik & 18 & 43.9 & 43.9 & 70.7 \\
& Baik & 8 & 19.5 & 19.5 & 90.2 \\
& Cukup & 3 & 7.3 & 7.3 & 97.6 \\
& Kurang & 1 & 2.4 & 2.4 & 100.0 \\
& Tidak & 1 & 100.0 & 100.0 & \\
& Total & 41 & & &
\end{tabular}

Novel Teror di Gunung Ciremai menurut sebagian besar pembaca usia SMP memiliki nilai pendidikan. Sebanyak $97,6 \%$ pembaca menganggap novel tersebut memiliki nilai pendidikan. Hanya $2,4 \%$ pembaca yang menyatakan bahwa novel tersebut tidak memberikan nilai pendidikan terhadap pembaca.

Tabel 13. Pemahaman Siswa SMP terhadap Pesan terhadap Nilai Sosial pada Novel Teror di Gunung

\begin{tabular}{rlrrrr}
\multicolumn{6}{c}{ Ciremai } \\
\hline \multirow{4}{*}{ Valid } & Frequency & Percent & Valid Percent & Cumulative Percent \\
\hline & Sangat Baik & 13 & 31.7 & 31.7 & 31.7 \\
& Baik & 15 & 36.6 & 36.6 & 68.3 \\
& Cukup & 10 & 24.4 & 24.4 & 92.7 \\
& Kurang & 3 & 7.3 & 7.3 & 100.0 \\
& Total & 41 & 100.0 & 100.0 & \\
\hline
\end{tabular}

Novel Teror di Gunung Ciremai menurut sebagian besar pembaca usia SMP memiliki nilai sosial. Yakni sebanyak $92,7 \%$ pembaca menganggap novel tersebut memiliki nilai sosial. Hanya $7,3 \%$ pembaca yang menyatakan bahwa novel tersebut tidak memberikan nilai sosial terhadap pembaca.

Pengaruh Kompetensi Novel Teror di Gunung Ciremai terhadap Perkembangan Remaja SMP

Selain mengukur pemahaman pembaca terhadap novel, penulis juga mengukur pengaruh novel terror di Gunung Ciremai bagi pembaca. Pengaruh yang diukur yakni pengaruh untuk mendaki gunung dan pengaruh untuk mencintai lingkungan. Berikut penjelasan mengenai pengaruh kompetensi novel terror di Gunung Ciremai bagi pembaca. 
Tabel 14. Pengaruh Novel Teror di Gunung Ciremai dalam Motivasi Siswa SMP di Tangerang Selatan untuk Mendaki Gunung

\begin{tabular}{rlrrrr}
\hline & Frequency & Percent & Valid Percent & Cumulative Percent \\
\hline \multirow{4}{*}{ Valid } & Sangat Baik & 11 & 26.8 & 26.8 & 26.8 \\
& Baik & 9 & 22.0 & 22.0 & 48.8 \\
& Cukup & 8 & 19.5 & 19.5 & 68.3 \\
& Kurang & 7 & 17.1 & 17.1 & 85.4 \\
& Tidak & 6 & 14.6 & 14.6 & 100.0 \\
& Total & 41 & 100.0 & 100.0 & \\
\hline
\end{tabular}

Setelah membaca novel Teror di Gunung Ciremai, siswa SMP di Tangerang Selatan termotivasi untuk mendaki gunung. Hal itu dibuktikan dengan tingginya ketertarikan siswa untuk mendaki gunung dengan jumlah $68,3 \%$ siswa. Adapun siswa yang tidak tertarik untuk mendaki gunung sebanyak $14,6 \%$ saja. Adapun siswa yang kurang tertarik untuk mendaki gunung sebanyak $17,1 \%$ siswa.

Tabel 15. Pengaruh Novel Teror di Gunung Ciremai dalam Motivasi Siswa SMP di Tangerang Selatan untuk Mencintai Lingkungan

\begin{tabular}{rlrrrr}
\hline & & Frequency & Percent & Valid Percent & Cumulative Percent \\
\hline \multirow{4}{*}{ Valid } & 28 & 68.3 & 68.3 & 68.3 \\
& Sangat Baik & 10 & 24.4 & 24.4 & 92.7 \\
& Baik & 2 & 4.9 & 4.9 & 97.6 \\
& Cukup & 1 & 2.4 & 2.4 & 100.0 \\
& Kurang & & 1 & 100.0 & \\
\hline
\end{tabular}

Setelah membaca novel Teror di Gunung Ciremai, siswa SMP di Tangerang Selatan termotivasi untuk mencintai lingkungan. Hal itu dibuktikan dengan tingginya ketertarikan siswa untuk mendaki gunung dengan jumlah 97,6\% siswa. Adapun siswa yang kurang tertarik untuk mencintai lingkungan sebanyak $2,4 \%$ saja

Pemahaman Siswa SMA/SMK di Tangerang Selatan terhadap Novel Teror di Gunung Ciremai

Berikut penjelasan pemahaman siswa SMA/SMK di Tangerang Selatan terhadap novel Teror di Gunung Ciremai.

Tabel 16. Pemahaman Siswa SMA/SMK terhadap Pesan Moral pada Novel Teror di Gunung Ciremai

\begin{tabular}{llcccc}
\hline & & Frequency & Percent & Valid Percent & Cumulative Percent \\
\hline \multirow{6}{*}{ Valid } & 31 & 50.0 & 50.0 & 50.0 \\
& Sangat Baik & 18 & 29.0 & 29.0 & 79.0 \\
& Baik & 10 & 16.1 & 16.1 & 95.2 \\
& Kukup & 1 & 1.6 & 1.6 & 96.8 \\
& Turang & 2 & 3.2 & 3.2 & 100.0 \\
& Tidak & 62 & 100.0 & 100.0 & \\
\hline
\end{tabular}

Novel Teror di Gunung Ciremai menurut sebagian besar pembaca usia SMA/SMK memiliki pesan moral. Sebanyak $95,2,1 \%$ pembaca menganggap novel tersebut memiliki pesan moral. Hanya 3,2\% pembaca yang menyatakan bahwa novel tersebut tidak memberikan pesan moral terhadap pembaca. Sebanyak 1,6\% siswa menyatakan novel tersebut kurang memberikan pesan moral. 
Tabel 17. Pemahaman Siswa SMA/SMK terhadap Pesan terhadap Nilai Pendidikan pada Novel Teror di Gunung Ciremai

\begin{tabular}{cccccc}
\hline & & Frequency & Percent & Valid Percent & Cumulative Percent \\
\hline \multirow{6}{*}{ Valid } & Sangat Baik & 20 & 32.3 & 32.3 & 32.3 \\
& Baik & 26 & 41.9 & 41.9 & 74.2 \\
& Cukup & 12 & 19.4 & 19.4 & 93.5 \\
& Kurang & 2 & 3.2 & 3.2 & 96.8 \\
& Tidak & 2 & 3.2 & 3.2 & 100.0 \\
& Total & 62 & 100.0 & 100.0 & \\
\hline
\end{tabular}

Novel Teror di Gunung Ciremai menurut sebagian besar pembaca usia SMA/SMK memiliki nilai pendidikan. Sebanyak $95,6 \%$ pembaca menganggap novel tersebut memiliki nilai pendidikan. Hanya 3,2\% pembaca yang menyatakan bahwa novel tersebut tidak memberikan nilai pendidikan terhadap pembaca. Sebanyak 3,2\% siswa lainnya menganggap novel tersebut kurang mengajarkan nilai pendidikan.

Tabel 18. Pemahaman Siswa SMA/SMK terhadap Pesan terhadap Nilai Sosial pada Novel Teror di

\begin{tabular}{cccccc}
\multicolumn{6}{c}{ Gunung Ciremai } \\
\hline \multirow{6}{*}{ Valid } & Frequency & Percent & Valid Percent & Cumulative Percent \\
& Sangat Baik & 19 & 30.6 & 30.6 & 30.6 \\
& Baik & 31 & 50.0 & 50.0 & 80.6 \\
& Cukup & 11 & 17.7 & 17.7 & 98.4 \\
& Tidak & 1 & 1.6 & 1.6 & 100.0 \\
& Total & 62 & 100.0 & 100.0 & \\
\hline
\end{tabular}

Novel Teror di Gunung Ciremai menurut sebagian besar pembaca usia SMA/SMK memiliki nilai sosial. Sebanyak $98,4 \%$ pembaca menganggap novel tersebut memiliki nilai sosial. Hanya $1,6 \%$ pembaca yang menyatakan bahwa novel tersebut tidak memberikan nilai sosial terhadap pembaca.

\section{Pengaruh Kompetensi Novel terhadap Perkembangan Remaja SMA/SMK}

Adapun penjelasan pengaruh kompetensi novel terhadap perkembangan remaja sekolah menengah akhir di Tangerang Selatan sebagai berikut :

Tabel 19. Pengaruh Novel Teror di Gunung Ciremai dalam Motivasi Siswa SMA/SMK di Tangerang Selatan untuk Mendaki Gunung

\begin{tabular}{cccccc}
\hline & & Frequency & Percent & Valid Percent & Cumulative Percent \\
\hline \multirow{6}{*}{ Valid } & Sangat Baik & 15 & 24.2 & 24.2 & 24.2 \\
& Baik & 14 & 22.6 & 22.6 & 46.8 \\
& Cukup & 21 & 33.9 & 33.9 & 80.6 \\
& Kurang & 3 & 4.8 & 4.8 & 100.0 \\
& Tidak & 9 & 14.5 & 14.5 & 100.0 \\
\hline
\end{tabular}

Setelah membaca novel Teror di Gunung Ciremai, siswa SMA/SMK di Tangerang Selatan termotivasi untuk mendaki gunung. Hal itu dibuktikan dengan tingginya ketertarikan siswa untuk mendaki gunung dengan jumlah $80,7 \%$ siswa. Adapun siswa yang tidak tertarik 
untuk mendaki gunung sebanyak $14,5 \%$ saja. Adapun siswa yang kurang tertarik untuk mendaki gunung sebanyak $4,8 \%$ siswa.

Tabel 20. Pengaruh Novel Teror di Gunung Ciremai dalam Motivasi Siswa SMA/SMK di Tangerang Selatan untuk Mencintai Lingkungan

\begin{tabular}{cccccc}
\hline & & Frequency & Percent & Valid Percent & Cumulative Percent \\
\hline \multirow{4}{*}{ Valid } & Sangat Baik & 42 & 67.7 & 67.7 & 67.7 \\
& Baik & 16 & 25.8 & 25.8 & 93.5 \\
& Cukup & 2 & 3.2 & 3.2 & 96.8 \\
& Kurang & 2 & 3.2 & 3.2 & 100.0 \\
\hline
\end{tabular}

Setelah membaca novel Teror di Gunung Ciremai, siswa SMP di Tangerang Selatan termotivasi untuk mencintai lingkungan. Hal itu dibuktikan dengan tingginya ketertarikan siswa untuk mendaki gunung dengan jumlah 96,8\% siswa. Adapun siswa yang kurang tertarik untuk mencintai lingkungan sebanyak $3,2 \%$ saja.

\section{Pengaruh Kompetensi Novel Digital terhadap Perkembangan Remaja}

Penelitian berikutnya dilakukan untuk mengukur pengaruh novel digital terhadap perkembangan remaja sekolah menengah di Tangerang Selatan. Siswa diberikan 3 buah novel secara acak untuk dibaca. Siswa tidak dituntut untuk membaca semua novel namun hanya diminta membaca salah satu dan memahami novel yang dibacanya tersebut. Setelah dilakukan pengukuran didapatkan hasil bahwa 377 siswa membaca novel.

Surat Biru bercerita tentang sepucuk surat biru yang dapat mempertemukan banyak hati yang terpisahkan untuk bersatu kembali. Menjadi awal untuk menciptakan kebahagiaan. Namun Bagi Yuri, si pengantar surat, kebahagiaan adalah sesuatu yang tidak pantas didapatkannya. Namun seorang lelaki pecinta musik bernama Dirga menemukan cinta pertamanya dalam diri gadis itu. Dirga ingin membuat gadis itu bahagia. Namun ada banyak hal yang harus mereka hadapi. Orang-orang dari masa lalu, konflik dari dalam diri mereka sendiri, serta kebimbangan pada sebuah pilihan.

Sementara novel Hati Tak Bertuan merupakan novel yang bercerita tentang puisi berjudul Hati Tak Bertuan yang telah menyita banyak perhatian. Tidak ada yang mengetahui siapa pencipta puisi tersebut. Itulah sebabnya seorang perempuan berumur dua puluh lima tahun bernama Aretha dituduh sebagai plagiat. Hal tersebut dikarenakan karya tersebut telah menjadi hak paten salah satu rumah produksi. Karya itu divisualisasikan menjadi film dengan judul yang sama. Namun, rumah produksi tersebut tetap menyembunyikan identitas sang pencipta puisi. Semua orang hanya mengetahui penulis dengan inisial, R. Itulah prolog dari novel "Hati Tak Bertuan". Novel ini berkisah tentang seorang penulis muda yang tidak pernah membuka identitas setiap karya besarnya sampai-sampai dituduh sebagai plagiat, namun dia tetap bergeming dengan pendiriannya. Di setiap karya yang dituangkannya merupakan goresan luka kehidupannya.Utamanya dalam hal percintaan. Dia tidak ingin semua orang tahu akan keluh kesahnya.

Tabel 21. Jumlah Siswa yang Membaca Novel

\begin{tabular}{|c|c|c|c|c|c|}
\hline & & Frequency & Percent & Valid Percent & Cumulative Percent \\
\hline \multirow{2}{*}{ Valid } & Angan Senja & 127 & 33.7 & 33.7 & 33.7 \\
\hline & Surat Biru & 82 & 21.8 & 21.8 & 55.4 \\
\hline
\end{tabular}




\begin{tabular}{lrrrr}
\hline Hati Tak Bertuan & 168 & 44.6 & 44.6 & 100.0 \\
Total & 377 & 100.0 & 100.0 & \\
\hline
\end{tabular}

Jumlah pembaca novel Angin Senja sebanyak 127 siswa (33,7\%. Jumlah pembaca novel Surat Biru sebanyak 82 siswa $(21,8 \%)$. Adapun jumlah siswa yang membaca novel Hati Tak Bertuan sebanyak 168 siswa $(44,6 \%)$. Jumlah total pembaca novel tersebut sebanyak 377. Pembaca novel lebih banyak dibandingkan siswa yang memiliki minat baca yakni 268 . Artinya mengalami peningkatan sebanyak 109 siswa (40,67\%).

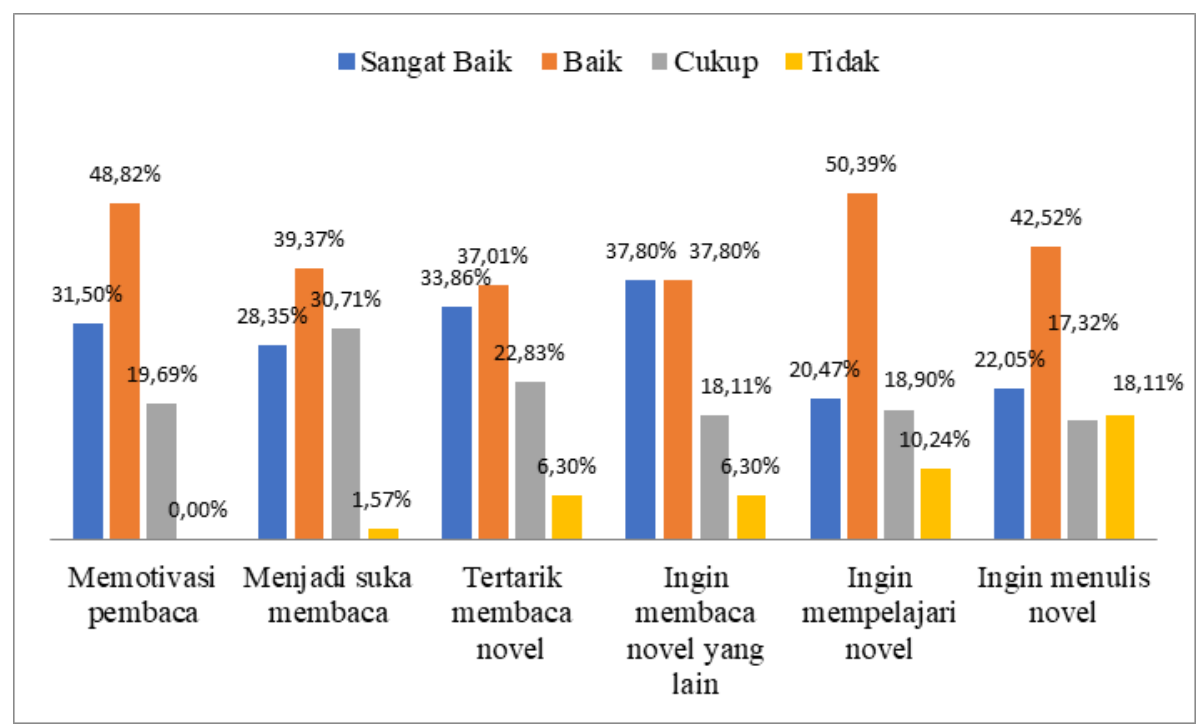

Gambar 4. Pengaruh Novel Angin Senja terhadap Siswa

Pengaruh yang diukur dalam novel terhadap pembaca yaitu pengaruh motivasi, seperti cerita dalam novel, minat baca, ketertarikan terhadap novel, ketertarikan mempelajari novel dan minat untuk menulis novel. Novel Angin Senja memotivasi pembaca. Hal itu dibuktikan dengan $31,50 \%$ pembacanya merasa sangat termotivasi, $48,82 \%$ pembacanya termotivasi dan $19,69 \%$ pembacanya cukup termotivasi.

Novel Angin Senja juga memengaruhi pembacanya menjadi suka membaca. Hal itu dibuktikan dengan hanya $1,57 \%$ saja pembacanya yang tidak suka membaca. Sementara $28,35 \%$ pembacanya sangat termotivasi, 39,37 pembacanya termotivasi, dan $30,71 \%$ pembacanya cukup termotivasi.

Novel Angin Senja juga mampu memengaruhi pembacanya menjadi tertarik membaca novel. Hanya $6,3 \%$ pembaca saja yang tidak tertarik membaca novel. Sisanya sebanyak $93,7 \%$ pembaca menjadi tertarik untuk membaca novel, dengan rincian; 33,86\% pembaca sangat tertarik, $37,01 \%$ pembaca tertarik, dan 22,83\% pembaca cukup tertarik untuk membaca novel. Pembaca novel Angin Senja juga merasa ingin membaca novel yang lain. Sebanyak 93,7\% pembaca tertarik. Sisanya sebanyak $6,3 \%$ pembaca tidak tertarik untuk membaca novel yang lain. Selain itu, $89,76 \%$ pembaca tertarik untuk mempelajari novel. Hanya 10,24\% pembaca yang tidak tertarik untuk mempelajari novel. 
Novel Angin Senja juga menginspirasi pembaca untuk menulis novel. Pembaca yang termotivasi untuk menulis novel sebanyak $81,89 \%$ siswa. Sisanya sebanyak $18,11 \%$ tidak termotivasi untuk untuk menjadi penulis novel.

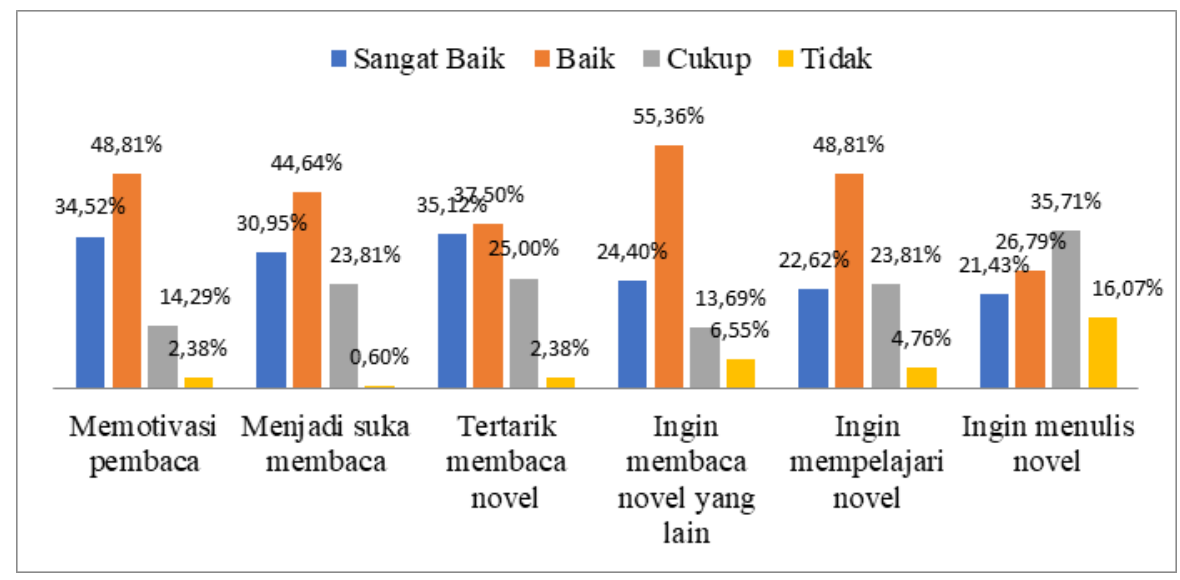

Gambar 5. Pengaruh Novel Hati Tak Bertuan terhadap Siswa

Pengaruh yang diukur dalam novel terhadap pembaca yaitu motivasi, minat baca, ketertarikan terhadap novel, ketertarikan mempelajari novel dan minat untuk menulis novel. Novel Hati Tak Bertuan memotivasi pembaca. Hal itu dibuktikan dengan 34,52\% pembacanya merasa sangat termotivasi, $48,81 \%$ pembacanya termotivasi dan $14,29 \%$ pembacanya cukup termotivasi. Sisanya sebanyak $2,38 \%$ pembaca tidak termotivasi.

Novel Hati Tak Bertuan juga memengaruhi pembacanya menjadi suka membaca. Hal itu dibuktikan dengan hanya $0,60 \%$ saja pembacanya yang tidak suka membaca novel. Sementara $30,95 \%$ pembacanya sangat termotivasi. Sebanyak 44,64\% pembacanya termotivasi. Selanjutnya, sebanyak $23,81 \%$ pembacanya cukup termotivasi.

Novel Hati Tak Bertuan juga mampu memengaruhi pembacanya menjadi tertarik membaca novel. Hanya $2,38 \%$ pembaca saja yang tidak tertarik membaca novel. Sisanya sebanyak $93,62 \%$ pembaca menjadi tertarik untuk membaca novel dengan rincian 35,12\% pembaca sangat tertarik, sebnayak $37,50 \%$ pembaca tertarik, dan $25 \%$ pembaca cukup tertarik untuk membaca novel.

Pembaca novel Hati tak Bertuan juga merasa ingin membaca novel yang lain. Sebanyak 93,45\% pembaca tertarik. Sisanya sebanyak 6,55\% pembaca tidak tertarik untuk membaca novel yang lain. Selain itu, 95,24\% pembaca tertarik untuk mempelajari novel. Hanya 4,76\% pembaca yang tidak tertarik untuk mempelajari novel.

Novel Hati Tak Bertuan juga menginspirasi pembaca untuk menulis novel. Pembaca yang termotivasi untuk menulis novel sebanyak $83,83 \%$ siswa. Sisanya sebanyak $16,07 \%$ tidak termotivasi untuk untuk menjadi penulis novel. 


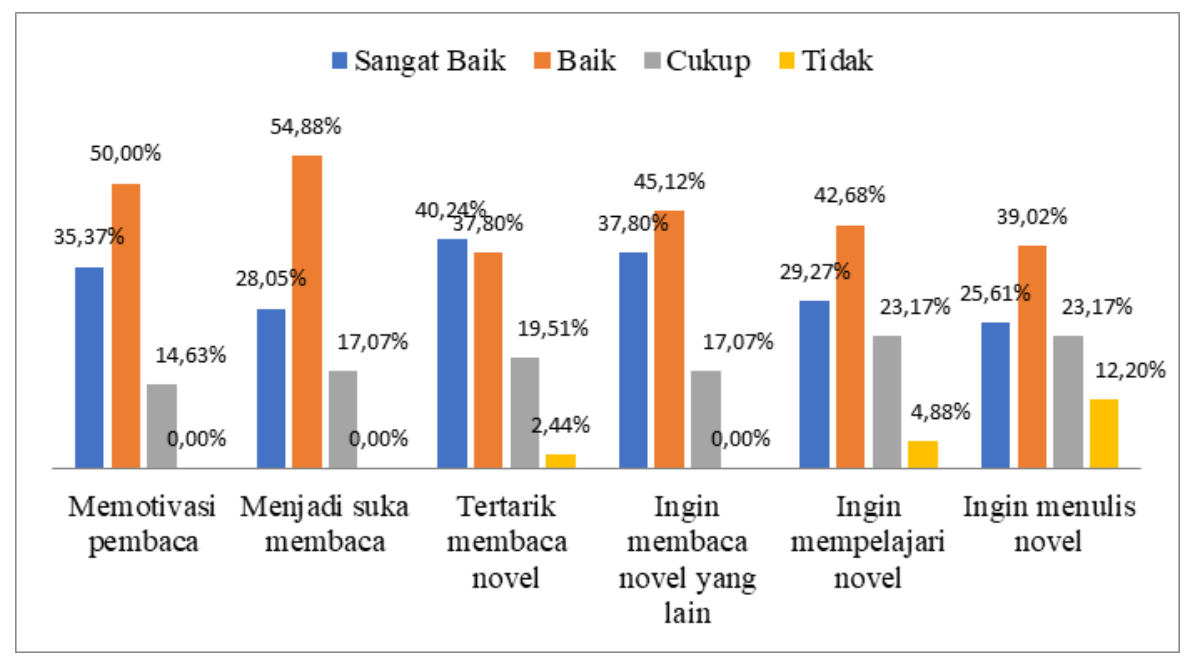

Gambar 6. Pengaruh Novel Surat Biru terhadap Siswa

Pengaruh novel terhadap pembaca yang diukur yaitu motivasi, minat baca, ketertarikan terhadap novel, ketertarikan mempelajari novel dan minat untuk menulis novel. Novel Surat Biru mampu memotivasi semua pembaca. Hal itu dibuktikan dengan 35,37\% pembacanya merasa sangat termotivasi, $50 \%$ pembacanya termotivasi dan $14,63 \%$ pembacanya cukup termotivasi.

Novel Surat Biru juga memengaruhi pembacanya menjadi suka membaca. Hal itu dibuktikan dengan semua pembacanya suka membaca novel. Adapun rinciannya sebanyak $28,05 \%$ pembacanya sangat termotivasi. Sebanyak $54,88 \%$ pembacanya termotivasi. Selanjutnya, sebanyak $17,07 \%$ pembacanya cukup termotivasi.

Novel Surat Biru juga mampu memengaruhi pembacanya menjadi tertarik membaca novel. Hanya $2,44 \%$ pembaca saja yang tidak tertarik membaca novel. Sisanya sebanyak $97,56 \%$ pembaca menjadi tertarik untuk membaca novel dengan rincian $40,24 \%$ pembaca sangat tertarik. Sebanyak 37,80\% pembaca merasa tertarik. Sebanyak 19,51\% pembaca cukup tertarik untuk membaca novel. Pembaca novel Surat Biru juga merasa ingin membaca novel yang lain. Semua pembaca novel Surat Biru tertarik untuk membaca novel yang lain. Selain itu, $95,12 \%$ pembaca tertarik untuk mempelajari novel. Hanya $4,88 \%$ pembaca yang tidak tertarik untuk mempelajari novel. Novel Surat Biru juga menginspirasi pembaca untuk menulis novel. Pembaca yang termotivasi untuk menulis novel sebanyak $17,80 \%$ siswa. Sisanya sebanyak $12,20 \%$ tidak termotivasi untuk untuk menjadi penulis novel.

\section{Simpulan}

Berdasarkan hasil penelitian pengaruh kompetensi novel terhadap perkembangan remaja di Tangerang Selatan didapatkan hasil: Pemahaman remaja usia sekolah menengah di Tangerang Selatan terhadap karya sastra novel sangat baik, yaitu $82,9 \%$ pada tingkat sekolah menengah pertama dan $70 \%$ pada tingkat sekolah menengah akhir. Pengaruh karya sastra novel terhadap pembaca remaja usia sekolah menengah di tangerang Selatan meliputi motivasi 
membaca, minat membaca, mempelajari karya sastra, dan memancing minat untuk menulis novel.

\section{Referensi}

[1] Noor R, Purnomo MH. Pengantar pengkajian sastra. Semarang: Fasindo; 2007.

[2] Abidin Y. Pembelajaran bahasa berbasis pendidikan karakter. Bandung: Refika Aditama; 2012.

[3] Nursalim MP, Aryani A, Hayati E. Bahasa Indonesia. Banten: Unpam; 2020.

[4] Lickona T. Educating for character: Mendidik untuk membangun karakter. Jakarta: Bumi Aksara; 2013.

[5] Saptono. Dimensi-dimensi pendidikan karakter: Wawasan, strategi, dan langkah praktis. Jakarta: Esensi Erlangga; 2011.

[6] Pribady H., Saman S. Aspektualitas Bahasa Melayu Dialek Sambas. Jurnal Pendidikan dan Pembelajaran Khatulistiwa. 2018; 6(6).

[7] Escarpit R. Sosiologi sastra. Ida Sundari Husen (penerjemah). Jakarta: Yayasan Obor Indonesia; 2008.

[8] Sugiyono D. Metode penelitian kuantitatif kualitatif dan R\&D. Bandung: Alfabeta; 2011.

[9] Santosa S. Menggunakan SPSS untuk statistik multivariat. Jakarta: Elex Media Computindo; 2014.

[10] Wachidah N. Persepsi pembaca terhadap novel Ayat-Ayat Cinta karya Habiburrahman El Shirazy dan implikasinya pada pembelajaran bahasa dan sastra Indonesia di sekolah. Skripsi. Jakarta: Jurusan Pendidikan Bahasa dan Sastra Indonesia, Fakultas Ilmu Tarbiyah dan Keguruan, Universitas Islam Negeri (UIN) Syarif Hidatullah; 2015.

[11] Sadono TP. Pengaruh mononton film $5 \mathrm{~cm}$ dan tingkat keakraban terhadap sikap nasionalisme mahasiswa Universitas Bunda Mulia. BRICOLAGE: Jurnal Magister Ilmu Komunikasi. 2019; $1(01)$. 